ISSN 2519-2523 (print)

Chornomors'ka mynuvshyna. - 2020. - No.15

DOI: $10.18524 / 2519-2523.2020 .15 .218689$

УДК 94:061.2(477.74)“"2005/2020”

\title{
BLACK SEA GAYDAMACK UNITY: 15 YEARS OF ACTIVITY
}

\author{
Uliana Hromovych \\ ORSID: https://orcid.org/0000-0001-6961-4906 \\ Master of history \\ Chief Specialist of Southern interregional department \\ Ukrainian Institute of National Remembrance \\ 26, Staroportofranktsivska Str., Odesa, 65020, Ukraine \\ gromovicula@gmail.com
}

The article offers information on the activities of the Black sea Gaydamack Unity for 15 years (2005-2020). The purpose, tasks and management of the society are defined. The information on measures on environmental protection, research and educational work with youth in the field of national-patriotic education is given.

Key words: modern Cossacks, Odesa region, Cossack society, Black Sea Gaydamack Unity

\section{ЧОРНОМОРСЬКЕ ГАЙДАМАЦЬКЕ З'ЄДНАННЯ: 15 РОКІВ ДІЯЛЬНОСТІ}

\author{
Уляна Громович \\ Магістр історії, головний спеціаліст \\ Південного міжрегіонального відділу \\ Українського Інституту національної пам’яті \\ Старопортофранківська, 26, Одеса, 65020 \\ gromovicula@gmail.com
}

У статті пропонується інформачія про діяльність Чорноморського Гайдамацького 3'єднання протягом 15 років (2005-2020). Визначено мету, завдання та керівний склад товариства. Подано інформацію про заходи щуодо охорони довкілля, науково-дослідну та виховну роботу з молоддю у сфері національно-патріотичного виховання.

Ключові слова: сучасне козаџтво, Одещина, козаџьке товариство, Чорноморське Гайдамацьке 3'єднання.

Українське козацтво - феноменальне явище світової історії. Південь України має глибокий і тісний зв'язок з українським козацтвом. І сьогодні в умовах незалежної України твориться сучасне українське козацтво, що являє собою систему самодіяльних об'єднань громадян України, мета яких - відродження традиційних козацьких цінностей. Воно відіграє важливу роль в політичному і культурному житті, разом з усім народом будує Українську суверенну державу.

Протягом останніх років становлення та розвитку сучасного козацтва на території Одеської області виникло чимало козацьких товариств. Одним із них $є$ громадська організація “Чорноморське Гайдамацьке 3'єднання”, що об'єднує навколо української національної ідеї тих, кому не байдуже минуле, сьогодення та майбутнє Батьківщини. 
Чорноморське Гайдамацьке 3'єднання (ЧГЗ) створене у 2005 р. Основні мета і завдання товариства - об'єднання зусиль українських патріотів в Одесі для:

- культурницької та історичної пропаганди української ідеї на Півдні України (дослідницький напрямок);

- наслідування дбайливого ставлення козацтва до навколишнього середовища (природоохоронний напрямок);

- охорони громадського порядку (правоохоронний напрямок);

- підготовки національно свідомої молоді (молодіжний напрямок);

- відродження традицій українського козацтва у сфері кінного спорту (кінноспортивний напрямок) [1, с. 208-209].

До керівного складу товариства входять: отаман Чорноморського Гайдамацького 3'єднання - Сергій Гуцалюк, історик, ветеран АТО, начальник Південного міжрегіонального відділу Українського інституту національної пам'яті; наказний отаман Чорноморського Гайдамацького 3'єднання - Олександр Голопотелюк, економіст, ветеран АТО, представник Одещини в Раді ветеранів України при Міністерстві у справах ветеранів України. Кількість членів ГО «Чорноморське Гайдамацьке 3'єднання» становить близько 200 осіб.

Гайдамаки співпрацюють 3 представниками громадських організацій i державних установ Одеси та Одеської області. Серед них особливе місце займає спільна робота 3 державним управлінням охорони довкілля в Одеській області, державною екологічною інспекцією з охорони довкілля північно-західного регіону Чорного моря, Одеським національним університетом імені I. І. Мечникова, відділом історії козацтва на Півдні України НДІ історії козацтва Національної академії наук України, з органами місцевого самоврядування.

Чорноморське Гайдамацьке 3'єднання має свій сайт: http://www.gaidamaky.od.ua/ та сторінку у соціальній мережі Facebook: @gaidamaky.od.ua, де постійно оновлюється інформація про роботу товариства. Діяльність Чорноморського Гайдамацького 3'єднання систематично висвітлюють одеські міські, регіональні та всеукраїнські 3МI.

В ЧГЗ функціонує екологічний підрозділ (керівник - Олексій Токмаков), який постійно здійснює рейди по Одеській області з охорони навколишнього середовища, серед яких: відстоювання території заповідного козацького дубу «Чорна ніч» у центрі Одеси, боротьба з браконьєрством на водах Тилігульського та Хаджибейського лиманів, участь у роботі міністерської комісії на Дністрі, виявлення незаконних смітників і шкідливих відходів переробки, затримання браконьєрів спільно 3 районними єгерями, виявлення фактів незаконної вирубки лісосмуг та багато іншого [2, с.190]. Чорноморські гайдамаки постійно разом 3 містянами беруть участь в суботниках на території Міського саду.

Науково-дослідний підрозділ Чорноморського Гайдамацького ’єднання (керівник - Володимир Полторак) проводить заходи зі збереження пам“яток козацької історії на території міста. Захищає від руйнування та постійно впорядковує разом 3 громадкістю Одеси два унікальних кладовища - Усатівське та Куяльницьке - 3 численними козацькими похованнями, найстаріші 3 яких датуються кінцем XVIII століття [2, с. 191]. Ці кладовища були визнані пам“ятниками історії та культури місцевого значення.

Козаками-гайдамаками також було встановлено пам'ятний хрест (2005р.) для вшанування подвигу загону запорозьких козаків на чолі з отаманом Семеном Палієм, 
який наприкінці березня 1691 року розгромив татарське військо, відпустив невільників і арештував цінних “язиків”.

Протягом 2006 - 2007 pр. науковцями Відділу історії козацтва на Півдні України на чолі $з$ доктором історичних наук, керівником Відділу Оленою Бачинською та козаками Чорноморського Гайдамацького 3'єднання було проведено пошукову роботу 3 виявлення та опису намогильних кам'яних хрестів, які вважаються козацькими у 9-ти селах Комінтернівського р-ну Одеської області: Петрівці, Каїрах, Калинівці, Широкому, Кордоні, Ранжевому, Любополі, Кошарах і Сичавці [1, с. 211]. У результаті дослідження було виявлено понад триста п'ятидесят надмогильних пам'ятників, які датуються кінцем XVIII - серединою XX ст.

Гайдамаки науково-дослідного підрозділу беруть активну участь в роботі всеукраїнських, регіональних та міжнародних наукових конференціях 3 козацької тематики. У 2019 р. представники ЧГЗ долучилися до проведення на березі Куяльницького лиману, в селі Корсунці першого великого етнофестивалю “Чумацький шлях. Сіль”.

32007 р. у рамках ЧГЗ діє молодіжний курінь (МК). Представники ЧГЗ проводять зустрічі з викладачами одеських ВНЗ та шкіл щодо співпраці та спільних заходів зі школярами та молоддю. Перше таборування відбулось на березі Тилігульського лиману Комінтернівського р-ну Одеської області - навчальний табір “Тилігульська Січ - 2007” [2, с. 190]. Козацький вишкіл пройшли два десятки козаків та козачок віком від 8 до 25 років. У своїй діяльності молодіжний курінь ЧГЗ плідно співпрацює зі спортивним козацьким клубом "Пластун-Характерник”, козаки якого займаються козацькими бойовими мистецтвами. А також співпраця проводиться 3 національною скаутською організацією України «Пласт: Одеса», культурнонаціональними організаціями та ін.

Козаки підрозділу співпрацюють з кінним клубом «Кубанка» (керівник - Марина Дрига) i безкоштовно навчають дітей с. Фонтанка верховій їзді та основам вольтижування i джигітування. Також члени товариства постійно проводять на запрошення директорів шкіл лекції для школярів з історії України про виникнення та формування українського козацтва, про козацькі походи та визначні битви, про історію українського війська та інше.

Козаки ЧГЗ беруть активну учать в організації та проведенні Всеукраїнської дитячо-юнацької військово-патріотичної гри «Сокіл» («Джура») серед команд учнів закладів загальної середньої освіти Одеської області. Мета якої полягає у вихованні юних патріотів України на основі національної гідності, високої самосвідомості та активної громадянської позиції, здорового способу життя духовно багатої та фізично розвиненої особистості. Члени товариства входять до складу суддівської колегії, таборової старшини та осавульської служби гри «Сокіл» ( «Джура»).

У квітні-травні 2020 р. Чорноморський науково-методичний ресурсний центр (структурний підрозділ ГО «Чорноморське Гайдамацьке 3’єднання», керівник - Зоя Дмитрук) організував в онлайн-форматі Одеську обласну школу виховників джур 3 метою підвищення методичного та практичного рівнів професійної компетентності фахівців 3 національно-патріотичного виховання (педагогічних працівників, громадських діячів, волонтерів). Чорноморський науково-методичний ресурсний центр розробив Освітню регіональну програму 3 організації та проведення підвищення кваліфікації фахівців 3 національно-патріотичного виховання, як методичне підгрунтя для проведення заходів Одеської обласної школи виховників джур, а для проведення семінарів, тренінгів, інших заходів [3, с. 1]. 
До складу Чорноморського Гайдамацького 3'єднання входять близько 40 учасників сучасної російсько-української війни на сході України, тому одним із важливих напрямків $є$ підтримка ветеранського руху. У 2019 р. представниками ЧГЗ створено ГО «Veterans Hub Odesa» (керівник - Олександр Голопотелюк) з метою допомогти участникам АТО, ветеранам, надати їм корисну інформацію щодо їхніх прав та можливостей згідно з діючими законами.

У вересні 2020 р. Чорноморське Гайдамацьке 3'єднання відзначило своє 15-річчя. В урочистих заходах взяли участь гайдамаки, друзі організації, представники духовенства, вчені-історики та військовослужбовці. Керівники 3'єднання нагородили козацькими хрестами всіх, хто пройшов 15-річний шлях організації разом, та тих, хто приєднався за цей час до спільної справи.

Одеське козацтво активно розвиває свою діяльність у різних галузях суспільного життя і це радує. Досвід діяльності Чорноморського Гайдамацького 3'єднання може стати корисним для інших козацьких товариств в Україні, що в свою чергу буде сприяти якісному підвищенню значення і ролі сучасного Українського козацтва, яке «вдень і вночі, і на суші, на воді - на захисті України!».

Бажаємо успіху козакам Чорноморського Гайдамаџького 3'єднання, їх гідній $i$ важливій для нашого народу справі!

\section{Джерела та література:}

1. Одеса козацька: наукові нариси. 2-е вид., випр. і доп. / О. А. Бачинська, Т. Г. Гончарук, С. Б.Гуцалюк, В. І. Кіров, А. І. Мисечко, Л. В. Новікова, В. М. Полторак. - Одеса : Феникс, 2008. $-239 \mathrm{c}$.

2. Гуцалюк С. Одеські гайдамаки у 2006-2007 pp. / С. Гуцалюк, В. Кіров // Чорноморська минувшина. - 2007. - Вип. 2. - С.189-192.

3. Освітня регіональна програма організації та проведення підвищення кваліфікації фахівців 3 національно-патріотичного виховання (педагогічних працівників, громадських діячів, волонтерів) [Електронний ресурс] // Чорноморський науково-методичний ресурсний центр ГО «Чорноморське гайдамацьке з’єднання» (упорядник програми Дмитрук 3. А.). - Одеса. 12 c. - Режим доступа: https://bit.ly/2Wuc5kV (дата 01.12.2020). - Назва з екрану.

\section{References:}

1. Odesa kozatska: naukovi narysy, 2008. 2nd edn. Odesa: Feniks. [in Ukrainian].

2. Gutsalyuk, S. \& Kirov, V., 2007. Odessa Haidamaks in 2006-2007. Chornomorska mynuvshyna, 2, pp.189-192. [in Ukrainian].

3. Osvitnia rehionalna prohrama orhanizatsii ta provedennia pidvyshchennia kvalifikatsii fakhivtsiv z natsionalno-patriotychnoho vykhovannia (pedahohichnykh pratsivnykiv, hromadskykh diiachiv, volonteriv). Chornomorskyi naukovo-metodychnyi resursnyi tsentr HO «Chornomorske haidamatske ziednannia» (uporiadnyk prohramy Dmytruk Z. A.). [online]. Odesa. Available at: $<$ https://bit.ly/2Wuc5kV> [Accessed 01 December 2020]. [in Ukrainian].

Отримано: 05.12.2020 p. 